\title{
Conventional and organic cropping systems at Suitia III: Microbial activity in soils
}

\author{
HELVI HEINONEN-TANSKI \\ Department of Environmental Engineering, University of Kuopio, P.O.B. 6, \\ SF-70211 Kuopio, Finland
}

\begin{abstract}
From 1983 to 1988 the microbial activity of soil was measured by determining its nitrification potential, dehydrogenase activity, cellulolytic activity and respiration. The samples were Suitia silty clay soils under various types of conventional and organic cropping systems.

The soil microbial activity was the highest in both organic cattle farm plots in the ley phase and conventional cattle farm plots in the ley phase. The difference between these two ley soils was not clear, partly because of the considerable statistical variance, but the microbial activity of organic cattle farm plots in clover leys tended to be higher than in conventionally cultivated grass leys. This favourable effect on dehydrogenase activity was not detected after poor overwintering in organic cattle farm plots in annual clover in 1984 and Persian clover in 1985, but some effect on nitrification was found in 1984. In many cases, soil microbial activity was still increased two to three years after the leys. The soil nitrification activities were often higher in organic plant production plots than in conventional plant production plots, but the dehydrogenase activities and cellulose decompositions of organic plant production plots were similar to those in conventional diverse plant production or barley monoculture plots.
\end{abstract}

Index words: dehydrogenase, nitrification, cellulolysis, soil respiration, conventional, organic agriculture

\section{Introduction}

As FitzPatrick (1986) stated, soils can be considered our major natural resource, because most of our food and clothing are derived from them directly or indirectly. Thus it is extremely important that we cultivate our soils in the original meaning of the Latin word, so that the fertility of soils is as high and stable as possible. The influence of soil microorganisms on the fertility of soil has recognized and widely reviewed in many textbooks. Microorganisms are responsible for nutritional cycles and for the decomposition of natural and synthetic compounds, including pesticides. Microbes form humus and stir the soil, forming stable aggregates important both in preventing erosion and for soil water and gas economy.

The microbial activity of soil has been 
studied in many fertilisation studies, some of them very long-lasting (PoKÓRnA-Kozova \& NovàK, 1975; Eiland 1980; Gulyás et al. 1984; Müller, 1984). In above studies, inorganic and organic fertilisers, up to normal or double doses, have been found to increase both crop yields and many microbial activities as well as in a Finnish study (METtÄLÄ et al. 1982). In long-term experiments, EILAND (1980), Múller (1984) and Scherbakov (1984) found that organic manure increased the dehydrogenase activity and some other microbial parameters more than the equivalent amounts of inorganic fertilisers. In EILAND's (1981) experiment, farmyard manure increased the soil microbial activity more than did slurry manure of the same dry weight.

There are, however, only a few critical studies of the soil microbial activity affected by organic contra conventional cropping. Schröder (1980), using filter paper as the substrate, found that the dehydrogenase activity and cellulolysis were higher in two organically cultivated soils than in two conventionally cultivated soils, but when straw was used as the substrate, no difference was seen. In Bavaria, BECK (1986) compared the effects of conventional and organic agriculture, and found that microbial parameters such as the catalase and protease activities, ammonification and biomass were higher in organic agriculture, but the difference was statistically significant only for biomass. In the same Bavarian study, Diez and Weigelt (1986) found only slight differences in soil chemical properties; the phosphorus content was higher in conventional agriculture, and the magnesium content was higher in organic agriculture. BORCHERT (1986) found no clear differences in soil physical properties during the same experiment. Thus it is not clearly known whether the microbial activity is different between conventional and organic agriculture, or how soon this possible difference in microbial activity occurs after the change from conventional to organic agriculture. In spite of this lack of knowledge a transfer phase of two to three years is usually recommended or required before agricultural products may be sold as biological or as some other special products. The present study was done to answer these questions in one soil type. The soil in this study is very difficult for farming, as it has a fine structure and a high capacity to tighten thus reducing the gas and water exchange with the plant roots damaged by the anaerobic environment. Agricultural methods involving a fairly stable structure preventing tightening would therefore be useful in such types of heavy soil.

\section{Materials and methods}

The agricultural cropping system variants in Suitia silty clay soil were:

conventional cropping, with pesticides if needed

A1: barley monoculture, NPK fertilisation A2: cereal production, NPK fertilisation

A3: diverse plant rotation, NPK fertilisation B: cattle farm, slurry and NPK

\section{organic cropping}

C1: plant production, plant material composted

C2: plant production, plant material not composted

D1: cattle farm, slurry composted

D2: cattle farm, slurry

The rotations were begun a) either in the ley phase or b) in the cereal phase, both of variants B and D. All experiments were done as three parallel plots. The agricultural operations with plant rotations, fertilisation and the possible pesticide applications (in A and B variants), as well as the chemical and physical properties of the soil plots, are described in more detailed by HanNUKKALA et al. (1990).

The microbial activities of all soil plots were measured between 1983 and 1988. The dehydrogenase activity and nitrification were measured three times during the growing sea- 
sons, first in spring or early summer, at the turn of May and June, second in summer, at the turn of June and July, and third in late summer or autumn, at the turn of August and September. The decomposition of cellulose was measured only once. The soil respiration was measured only for some plots in 1987 and 1988.

The soil samples for analysis of the dehydrogenase activity and the nitrification potential were taken from the depth of $0-3$ $\mathrm{cm}$, from ten different sites in each plot and then mixed together. The determination for the dehydrogenase activity was started within $30 \mathrm{~h}$ after sampling. The TTC-method of Thalmann (1968), with the modification of MetTÄLÄ et al. (1982), was used. Nitrification potential, as brutto nitrification, was measured from air-dried soil following the oxidation of ammonium to nitrate (HEINONENTANSKI et al. 1985).

Cellulolytic activity was measured using the polyester bag (approx. $20 \mathrm{~cm} \times 5 \mathrm{~cm}$, net size $1.3 \mathrm{~mm}$ ) method. The bag contained $5.0 \mathrm{~g}$ of substrate, buried at a depth of $3 \mathrm{~cm}$. First, wheat straw was used as the substrate during the period beginning in autumn 1983 to the following autumn. Thereafter, filter paper (Schleicher \& Schüll 604) was used as the substrate in summer, with an incubation time of two to three months. In both cases, the substrate remaining after incubation was washed carefully, dried at room temperature and weighed. Cellulolysis was calculated on the basis of the weight loss.

Respiration was measured according to Witcamp's (1966) field method.

Tukey's test and the LSD one-way test were used for the dehydrogenase and nitrification activities and $t$-tests for the cellulolysis activity results. The correlation coefficients between the dehydrogenase activity and nitrification potential and the cellulolysis results, were calculated.

\section{Results}

All soil microbial activities were very simi- lar in organic plant production (C1 and $\mathrm{C} 2)$ and organic cattle farm plot (D1 and D2) cropping systems. Thus the difference in treatment according to whether the plant residues were composted or not-composted was not important; therefore only the means of $\mathrm{C} 1+\mathrm{C} 2$ and $\mathrm{D} 1+\mathrm{D} 2$ have been presented in Figures 1 and 2. The results of conventional barley monocultures A1 and cereal production plots A2 were also so similar that their means are presented in the same figures.

The dehydrogenase activities were highly dependent on the plant cultivated in soil and on the year (Figs. 1a and 1b). Thus the highest or lowest activities were in the same or almost the same plot in the same year in spite of the month when sampled. The most clear statistically significant differences (one-way test) were found for the plots with conventional farming in grass ley phases (B) and for organic clover cattle farming in well-growing clover ley phases (D1 and D2), which usually gave much higher dehydrogenase activities than all the other plots. This phenomenon was easily seen in the results for 1983, 1986 and 1987 in all the samplings. The dehydrogenase activities of both organic cattle farms that had grown annual clover ley in 1984, and Persian clover in 1985 (D1 and D2) were, however, very low after a very poor overwintering (KoRva \& VARIS 1990), and they were the lowest of all the variants in the springs 1984 and 1985. At the same time the dehydrogenase activities of conventional cattle farm plots in the ley phase (B) were still the highest of all the variants, though the values were low when compared to the other years. The dehydrogenase activities of these plots were again high after ley, in the cereal phase in the springs of 1986 and 1987. The difference in soil dehydrogenase activity for barley monoculture (A1) and the other cereals either in conventional (A2) or in organic plant production plots in the cereal phase ( $\mathrm{C} 1$ and $\mathrm{C} 2$ ) was not statistically significant, although the plots with the other cereals sometimes gave lower dehydrogenase activities than barley monoculture. The dehydrogenase activity of diverse rotation plots (A3) 


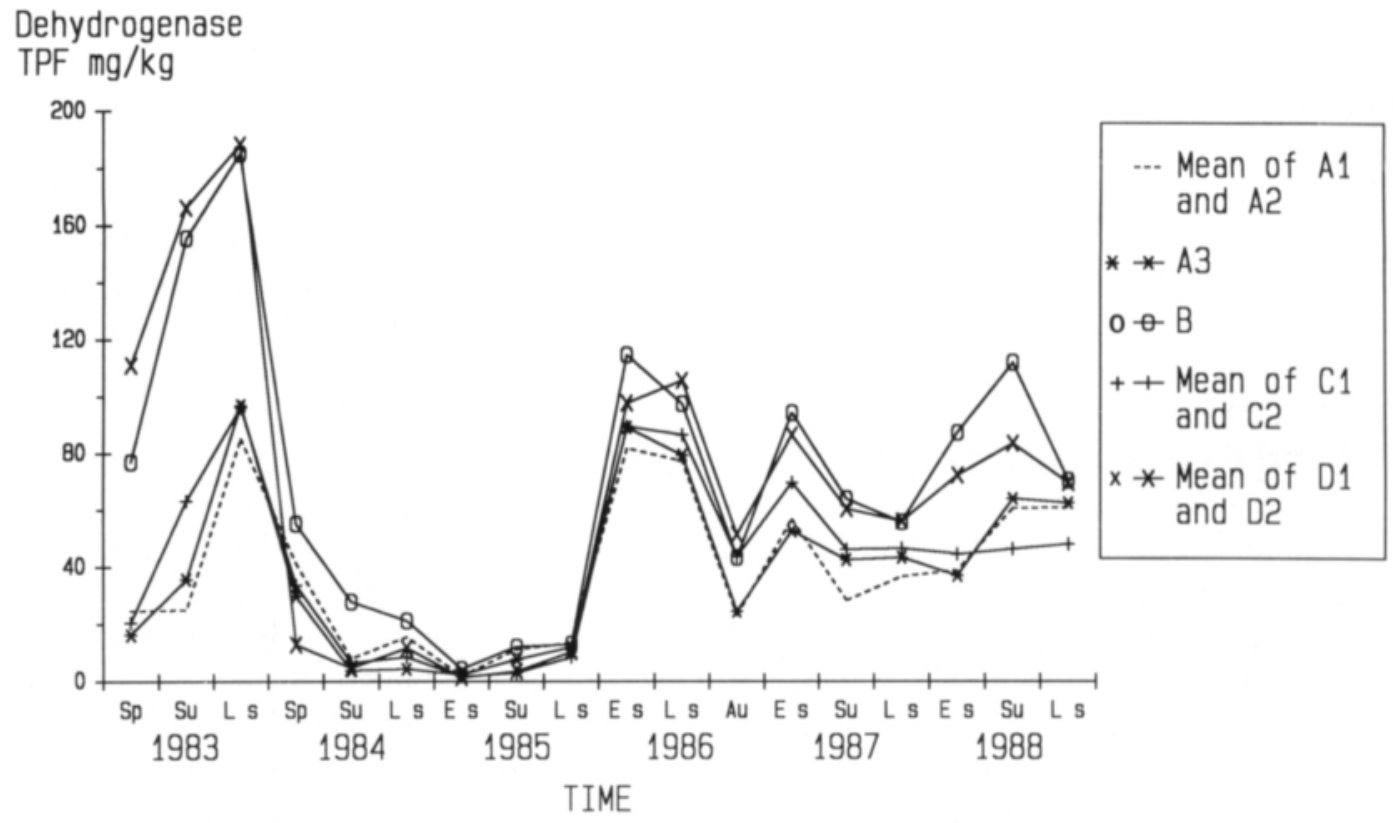

Fig. 1. a) The soil dehydrogenase activities in rotations beginning with ley $1983-1988$. Mean of $\mathrm{Al}=$ conventional barley monoculture and $\mathrm{A} 2=$ conventional diverse cereals, $\mathrm{A} 3=$ conventional plant production, $\mathrm{B}=$ conventional cattle farm including grass ley, $\mathrm{C} 1$ and $\mathrm{C} 2=$ organic plant production (composted or not composted), D1 and D2 = organic cattle farm plots including clover ley (composted or not composted). $\mathrm{Sp}=$ spring, Es = early summer, $\mathrm{Su}=\mathrm{summer}$, $\mathrm{Ls}=$ late summer and $\mathrm{Au}=$ autumn.

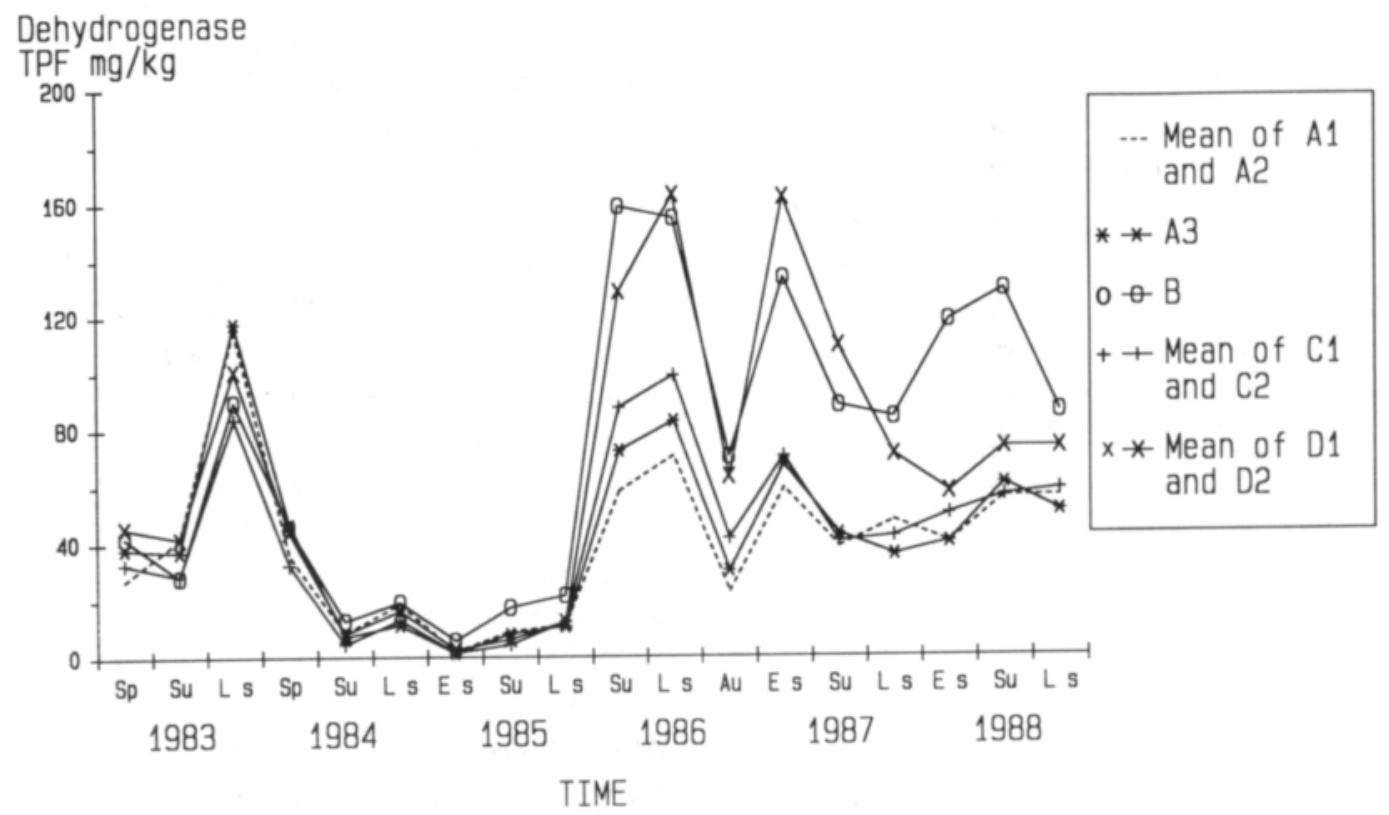

Fig. 1 . b) The soil dehydrogenase activities in rotations beginning with cereals in 1983-1988. For the rest of the legend, see Fig. la. 
Table 1. Summary of the plants cultivated in plots with the highest soil dehydrogenase activities (in order) differing statistically significantly from the others. Ley phase in 1983, 1984 and 1985 in a) and in 1986, 1987 and 1988 in b). For rotations, see HanNuKKala et al. (1990).

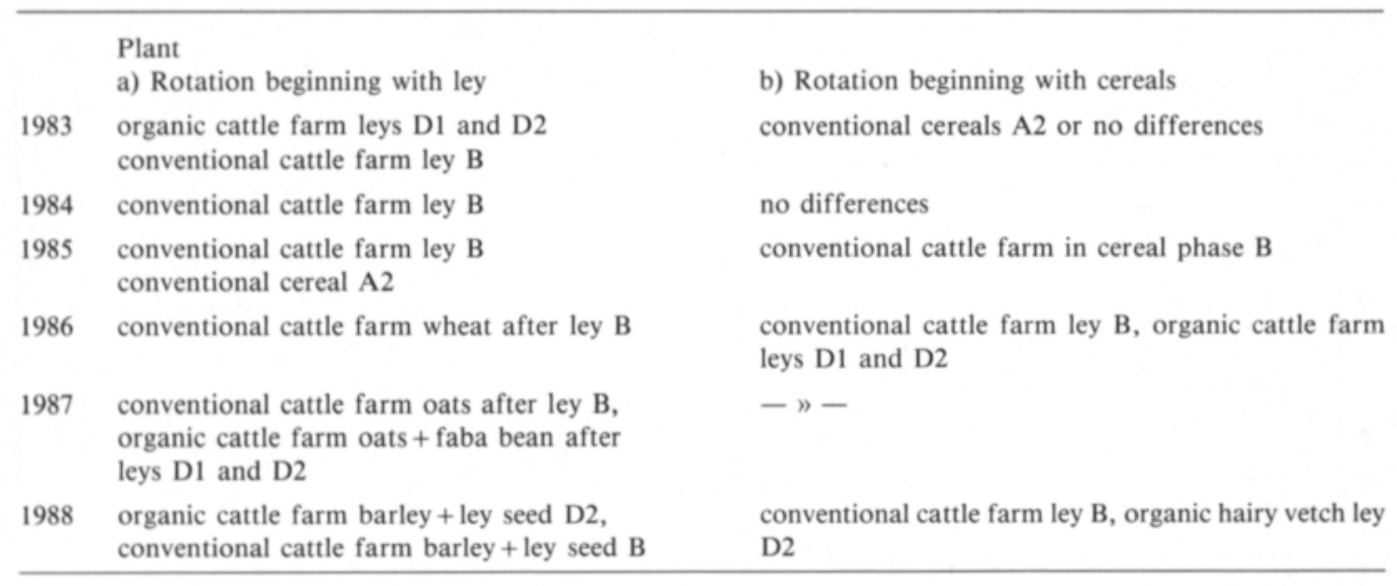

and organic plant production plots ( $\mathrm{C} 1$ and C2) cultivated with potato were the lowest obtained in those years. Generally, the dehydrogenase activities were lowest in 1984 and 1985 , owing to the poor overwintering.

Soil nitrifications were also high in all kinds of ley plots (B and D plots), more clearly since the second year's leys, and a favourable aftereffect was found (Figs. 2a and 2b). The effect of unsuccessful overwintering could be seen only in 1985. The statistical significance (with both one-way tests) between conventional cattle farm grass ley (B) and organic cattle farm clover leys (D's) was not clear because in some measurements the soil nitrifications were higher in organic clover leys than in conventional grass leys, and sometimes it was vice versa, but more often it was higher in organic cattle farm plots in the ley phase, especially in 1988 when hairy vetch was grown.

Quite often the organic plant production plots $(\mathrm{C} 1$ and $\mathrm{C} 2)$ showed high nitrification activities, which were statistically (one-way Tukey's or LSD test) significantly as high as the ley (B or D plots) and higher than the conventional plant production plots. Barley+ clover in 1983, potato in 1984 but not in 1987, barley + clover and green fallow in 1985, oats + faba bean in 1987 and barley + clover and green fallow in 1988 were cultivated in such cases. The same phenomenon was found in conventional plant production plots only in June 1987 in barley monoculture (A1) and in conventional cereal plots (A2), but the general nitrification activities that summer were low after long-lasting rains (see HANNUKKALA et al., 1990). Indeed, the mean nitrification of conventional plant production cropping (A3) under potato in 1987 was negative.

The parallel II, closest to the river and with ineffective drainage (see HanNUKKALA et al. 1990), gave some negative nitrification results in conventional plots (also ley B), indicating a high denitrification.

The correlation coefficient between the dehydrogenase and nitrification activities was $-0.141 \quad(p=0.001)$.

The cellulolysis activity with straw as the substrate in 1983-1984 was low (approx. $5-10 \%$ of weight loss) in all the plots, and the variation between parallel plots was high. Straw decomposition was highest in organic cattle farming at the ley phase, fertilised with non-composted plant residues (D2); the difference was statistically significant in the $t$-test $(p<0.05)$ when compared to the barley monoculture in two of three parallels.

The decomposition percentage of filter paper in two to three months was typically $20-40 \%$. In 1985, only a few bags could be 


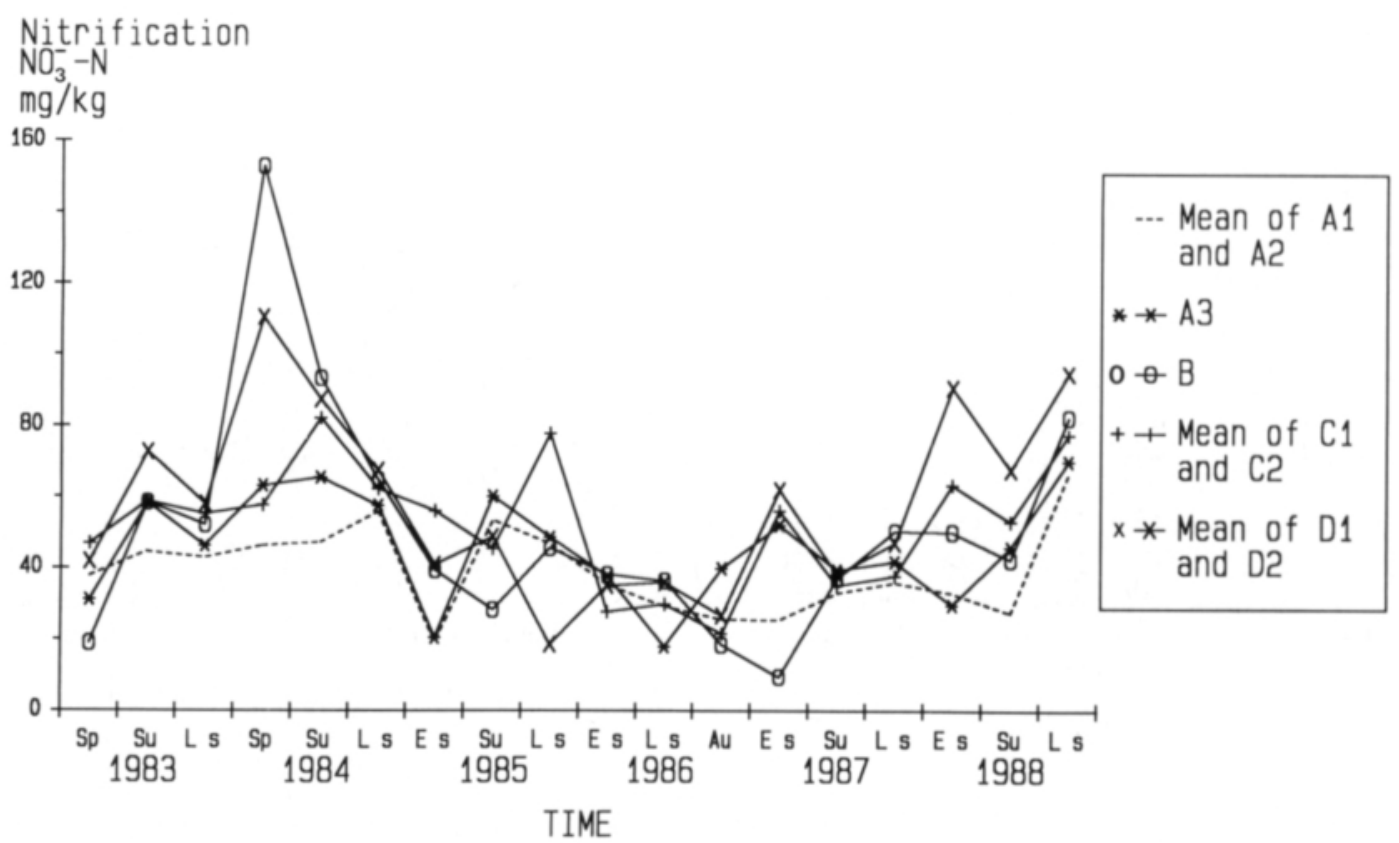

Fig. 2. a) The soil nitrifications in rotations beginning with ley in 1983-1988. For the rest of the legend, see Fig. 1a.

weighed; according to these results, no regular statistically significant differences in cellulose decomposition could be found. The results of one parallel were totally lacking in
1986. None of the results regularly showed statistically significantly different results when compared to the barley monoculture.

In 1987 the cellulolysis was very high (up

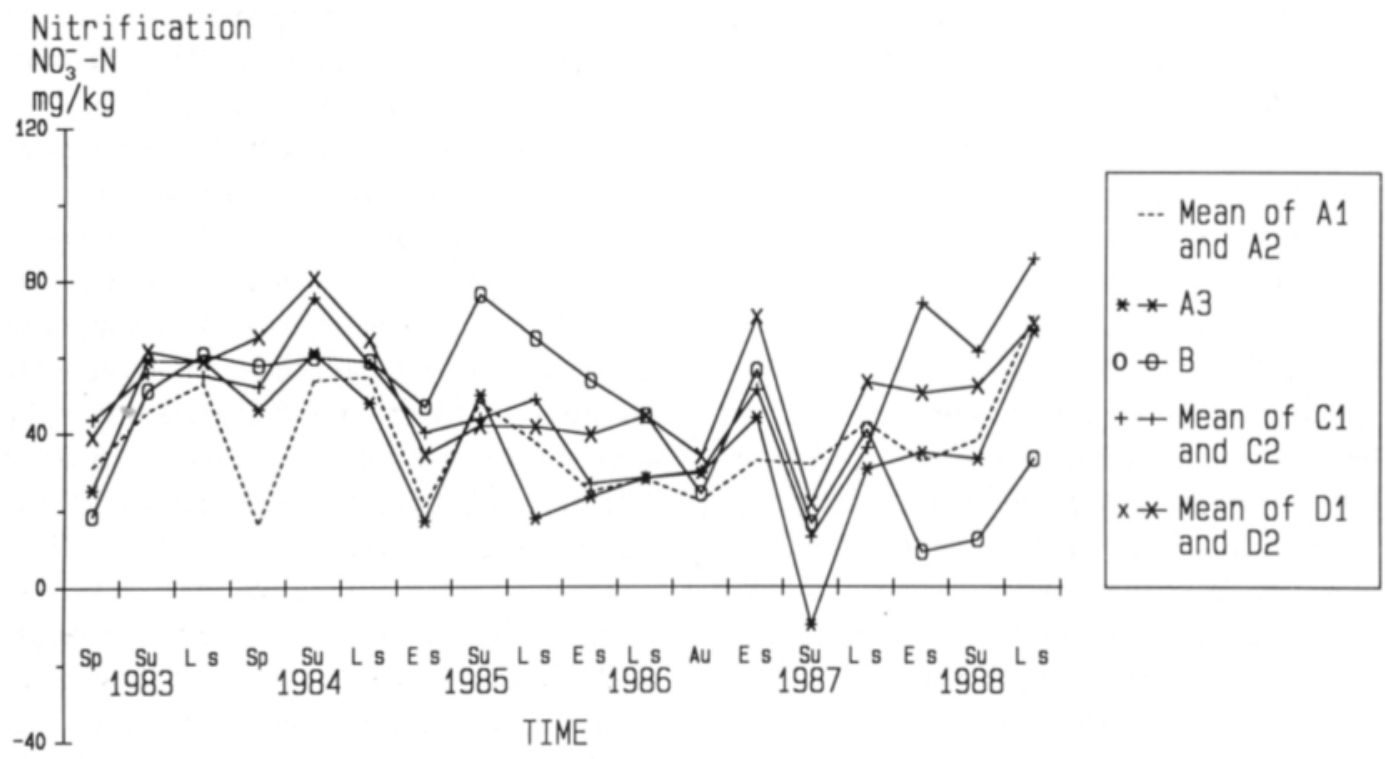

Fig. 2. b) The soil nitrifications in rotations beginning with cereals in 1983-1988. For the rest of the legend, see Fig. 1a. 


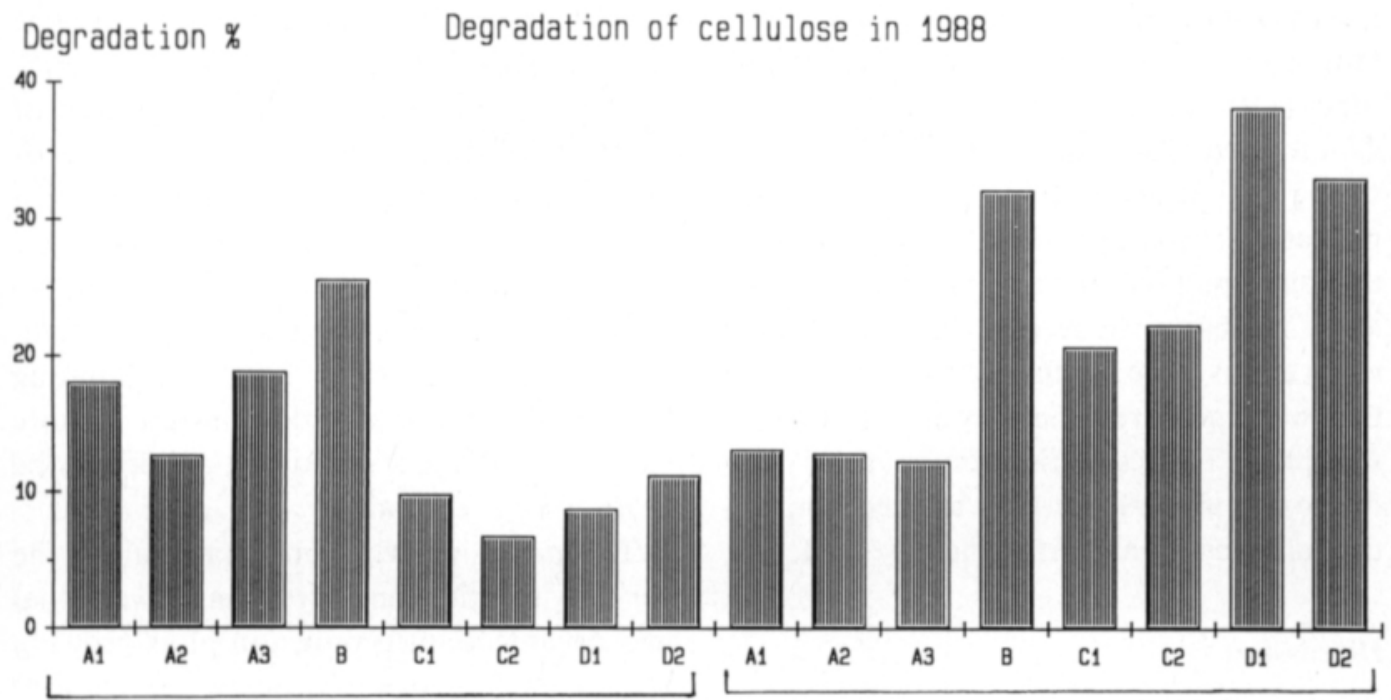

a

b

Plots

Fig. 3. The decomposition of cellulose in different rotation plots in 1988. The legend for rotation systems see Fig. 1a. a) in cereal phase, b) in ley phase.

to $60 \%$ ) when compared to the other years. The cellulolysis in conventional grass leycereals in the ley phase (B) and of organic cattle farm plots in the ley phase (D1 and D2) was higher than in barley monoculture, the statistical significance of the p-value being from 0.000 to 0.08 . The difference between conventional and organic cattle farms in the ley phase was not clear. The soil cellulolytic activity of organic plant production plots $(\mathrm{Cl}$ and C2) where potato was grown in 1987, was very low, but not statistically significantly different from that for the barley monoculture (A1).

In 1988 (Fig. 3), the conventional cattle farm (B) in the ley phase and organic cattle farms (D1 and D2) in the ley phase growing hairy vetch showed the highest cellulolytic activities, and were statistically significantly different from those for barley monoculture (p-values from 0.000 to 0.03 ). The cellulolysis was higher in organic cattle farms with hairy vetch than in conventional cattle farm with grass leys, but not statistically significantly.

The cellulolytic activity of organic cattle farming (D1 and D2) in the cereal phase (barley + ley seed in 1988) was, however, lower than in barley monoculture, the statistical significance of $p$ being from 0.000 to 0.07 . The cellulolytic activity had also decreased when compared to the barley monoculture both in the conventional diverse rotation (A3) and in the organic plant production plots $(\mathrm{Cl}$ and C2) growing barley + ley seed. The p-values ranged from 0.001 to 0.09 . The conventional cattle farm plots (B) in the cereal phase growing, also barley + ley seed in 1988 on the contrary had an increasing (statistically significant only in one of three parallels) effect compared to barley monoculture. Thus the soil cellulolytic activity of conventional cattle farms (B) was statistically $(\mathrm{p}<0.01-0.001)$ significantly higher than that of organic cattle farms (D's) both in the cereal phase.

The correlation coefficient between the dehydrogenase and cellulolytic activities (years $1983-84,1987$ and 1988 ) was 0.55 , with pvalue of 0.001 . The correlation coefficient between nitrification and cellulolysis was -0.12 , and it was not statistically significant. 
Respiration in soil in conventional barley monoculture (A1) and conventional cereal plots (A2) varied from 8 to $40 \mu \mathrm{mol} / \mathrm{hcm}^{2}$ $\mathrm{CO}_{2}$ formed. The respirations were highest in spring and decreased to autumn. There were no statistically significant differences between the soil respirations in barley monoculture and those for barley in cereal rotation. The soil respirations were much lower in 1988, when they were measured in barley and barley + ley seed plots. The respiration results varied from 0.7 to $1.1 \mu \mathrm{mol} / \mathrm{hcm}^{2} \mathrm{CO}_{2}$ formed. No statistically significant differences existed.

\section{Discussion}

The favourable effect of both conventional and organic cattle farms in grass ley or leguminous leys, including also the after-effect on the soil microbial activities, was very clear. The after-effect of ley was higher in conventional grass leys than on organic cattle farms, perhaps because of better growth.

The radical reduction of dehydrogenase activities in all plots, and especially in plots cultivated with clover or Persian clover in 1984-1985 on organic cattle farm plots, can be explaned by the fact that in the winter and spring ice cover almost totally killed the overwintering clover ley (KoRVA \& VARIS 1990). This shows very well the importance of plants, especially plants with large, long-growing roots, on soil microbial activity. The increasing effect of ley with large roots on the soil dehydrogenase activity was also reported by EILAND (1981). In some cases, ley seed production under barley may also have stimulated the microbial activity.

Often, but not always, the soil microbial activity of organic clover ley was higher than that of conventional grass ley, but this difference was significant only in very few cases.

The soil nitrification activity was often higher in organic cattle production plots than in conventional cattle production plots, both in the cereal phase. This result was obtained every year since 1983, when tested for the first time and the field trial was carried the second year. This may have led to a more economic use of nitrogen as nitrate in soils, when nitrogen was a limiting factor. The ley phases of the organic cattle farms also showed a tendency to have a higher nitrification activity than the conventional cattle farms with grass leys, especially in 1988, when both nitrate in organic plots and water because of dry, hot summer (HANNUKKALA et al. 1990) were limiting in all plots. In this situation, nitrate is more easily diluted and transported, and it may be more useful for plants.

The long rains, which may have caused the very low nitrifications in 1987 in conventional and organic plant production plots growing potato, may also have caused the reduced number of earthworms reported by NUUTINEN and HAUKKA (1990)

The soil dehydrogenase activity and cellulose decomposition of organic plant production plots ( $\mathrm{C} 1$ and $\mathrm{C} 2$ ) was usually low, and in some cases less than in barley monoculture. The soil dehydrogenase activity on organic cattle farms (D1 and D2) in the cereal phase was approximately the same as in conventional cereal cultivation. In 1988, this can be explained by the unsuccessful overwintering of the clover ley phase. It seems that good plant growth is necessary for good soil microbial activity, but good microbial activity of the soil does not yet guarantee good plant yields, as can be seen from the results of the present study and from the winter wheat yield results reported by KORVA and VARIS (1990), for instance, in 1986 of the A and B plots.

A slightly increased cellulolytic activity in organic plots as compared to more conventional plots was found in the experiments of Schröder (1980), El-Titi and LANDEs (1988) and by the present study in 1988. The high moisture content of soil in the summer of 1987 , with heavy rains, may explain the general high cellulolytic activity found in all plots, as pointed out by WiтcAmp (1966). The same moisture difference may also explain the difference in respiration results between 1987 and 1988 .

The dehydrogenase results were so similar 
in the same plots in the same summer under the same plant, that instead of three measuring times only one or two measuring times were needed, but the nitrification results were more diverse in the same plot even in the same growing season.

MOORE and RuSSELl (1972) very critically suggested that the dehydrogenase activity is unlikely to be a general index of soil fertility, but that it is a qualitative indication. In the present study, the dehydrogenase activities, however, proved to be sensitive to the effect of grass ley and clover ley - perhaps more sensitive than the other microbial parameters tested. Also the correlation coefficient of 0.55 between the cellulolytic and dehydrogenase activities with the very high statistical significance $(p=0.001)$, shows that both these parameters measure biological activity which is not the same, but they either belong loose- ly together or to a common factor, such as the carbon cycle in soil. This result agrees very well with the correlation coefficient value of 0.667 reported by MettäLÃ et al. (1982). Their coefficient, obtained in a smaller study, was not statistically significant.

The correlation between nitrification and cellulolytic or dehydrogenase activities was poor, indicating that these factors clearly measure different things and cannot substitute for each other.

Acknowledgements. I wish to thank many of my students for the microbial laboratory work. In particular, the work of Mrs Outi Zacheus (M.Sc.), who made her M.Sc. work at Suitia in 1987, deserves to be mentioned. Also the field agricultural personel has always been very helpful. Mrs Pirjo Halonen (M.Sc.) has helped and guided me with the statistical analyses made by computer. The English language has been corrected by Mrs Sevastiana Ruusamo (M.Sc.).

\section{References}

BECK, T. 1986. Bodenmikrobiologische Untersuchungen. Bayerisches Landwirtsch. Jahrb. 63: 996-1002.

BORCHERT, H. 1986. Bodenphysikalische Untersuchungen. Bayerisches Landwirtsch. Jahrb. 63: 991-996.

Diez, T. \& Weigelt, H. 1986. Vergleichende Bodenuntersuchungen von konventionell und alternativ bewirtschafteten Betriebsschlagen. Einführung, Untersuchungskonzept, spatendiagnostische und chemische Untersuchungen. Bayerisches Landwirtsch. Jahrb. 63: 979-991.

EILAND, F. 1980. The effects of manure and NPK on the soil microorganisms in a Danish long-term field experiments. Tidsskr. Planteavl. 84: 447-456.

- 1981. Organic manure in relation to microbiological activity in soil. Yield Potentials in Continental Climates. Proc. 16th Coll. Potash Institute, Bern pp. $147-156$.

El-Titı, A. \& Landes, H. 1988. The integrated farming system of Lautenbach: A practical contribution toward sustainable agriculture in Europe. Proc. Conf. Sustainable Agriculture. Ohio 23.-27.9.1988. Manuscript.

FitzPatrick, E.A. 1986. An Introduction to Soil Science. Longman Scientific \& Technical, Essex 2nd Ed. pp. 255.

Gulyás, F., Lásztily, B., Szzegi, J. \& Kádár, L. 1984. Cellulose decomposition in chernozem soil as affected by intensive fertilization. Soil Biology and Conservation of the Biosphere. Ed. J. Szegi. Akademiai Kiado, Budapest pp. 95-106.

Hannukkala, A.O., Korva, J. \& Tapio, E. 1990. Conventional and organic cropping systems at Suitia. I: Experimental design and summaries. J. Scient. agric. Soc. Finland 62: 295-307.

Heinonen-Tanski, H., Rosenberg, C., Siltanen, H., KilPI, S. \& Sıмолокı, P. 1985. The effect of the annual use of pesticides on soil microorganisms, pesticide residues in the soil and barley yields. Pestic. Sci. 16: $341-348$.

KorVA, J. \& VARIS, E. 1990. Conventional and organic cropping systems at Suitia. II: Crop growth and yields. J. Scient. agric. Soc. Finland 62: 309-319.

Mettãlā, A., Koponen, M., Pirinen, H. \& Korkman, J. 1982. The effect of fertilization and crop rotation on soil chemical and biological properties in field trials on a clay soil in Southern Finland. J. Scient. agric. Soc. Finland 54: 331-344.

Moore, A.W. \& Russell, J.S. 1972. Factors affected dehydrogenase as an index of soil fertility. Plant Soil 37: $675-682$.

Moller, G. 1984. Influence of mineral fertilization on the biological processes of the soil. Soil Biology and Conservation of the Biosphere. Ed. J. Szegi. Akademiai Kiado, Budapest pp 3-28. 
NuUtinen, V. \& HaukKa, J. 1990. Conventional and organic cropping systems at Suitia. VII: Earthworms. J. Scient. agric. Soc. Finland 62: 00.

Póónna-Kozova, J. \& Novàk, B. 1975. Der langfristige Einfluss der organischen und mineralischen Düngung auf den Boden. Zbl. Bakt. Abt II 130: 711-724.

Scherbakov, A.P. 1984. Effect of systematic manuring on the enzymatic activity of soil. Soil Biology and Conservation of the Biosphere. Ed. J. Szegi. Akademiai Kiado, Budapest pp 29-36.

Schroder, D. 1980. Stroh- und Celluloseabbau sowie Dehydrogenaseaktivităt in "biologisch" und "kon- ventionell" bewirtschafteten Böden. Landwirtsch. Forsch. Sonderh. 37: 169-175.

Thalmann, A. 1968. Zur Methodik der Bestimmung der Dehydrogenaseaktivität im Boden mittels Triphenyltetrazoliumchlorid (TTC). Landw. Forsch. 21: 249258.

Witcamp, M. 1966. Decomposition of leaf litter in relation to environment, microflora and microbial respiration. Ecology 2: 194-201.

Ms received July 12, 1990

\section{SELOSTUS}

\section{Suitian viljelyjärjestelmä \\ III: Maan mikrobiologinen aktiivisuus eri viljelykiertojärjestelmissä}

\author{
Helvi Heinonen-Tanski \\ Teknisen ympäristöhygienian laitos, \\ Kuopion yliopisto, Pl 6 \\ 70211 Kuopio
}

Maan mikrobiologista aktiivisuutta on tutkittu tavanmukaisissa ja luonnonmukaisissa kierrossa mittaamalla maan dehydrogenaasi, nitrifikaatio, selluloosan hajoaminen ja respiraatio.

Dehydrogenaasiaktiivisuuden ja selluloosan hajoamisen ero luonnonmukainen - tavanmukainen ei ollut merkittăvă Suitian hiesusavimailla viljelykierroissa, joissa ei ollut nurmea. Sitä vastoin luonnonmukaisten nurmettomien kiertojen maan nitrifikaatiot olivat usein korkeampia kuin nurmettomilla tavanmukaisilla maaruuduilla.

Sekä tavanmukainen heinänurmi että luonnonmukainen apilanurmi kohottivat erittäin selvästi maan mikrobiologista aktiivisuutta. Monissa tapauksissa luonnonmukaiset puna-apila- tai muita palkokasveja kasvaneet nurmet kohottivat mikrobiologista aktiivisuutta jonkin verran enemmän kuin tavanmukaiset heinänurmet, mutta ero ei ollut yleensả tilastollisesti merkittåvă. Selvin ero oli nitrifikaatiossa, joka useimmiten oli korkeampi luonnon- mukaisilla nurmilla kuin tavanmukaisilla. Korkea nitrifikaatiokyky merkitsee maassa typen tehokkaampaa käyttöä, jos typpi on kasvua voimakkaasti rajoittava tekijä. Jos sită vastoin maassa on runsaasti typpeä, korkea nitrifikaation seurauksena osa typestä voi huuhtoutua pois - varsinkin sateisina vuosina.

Nurmilla oli vielä erittåin selvă jălkivaikutus, joka näkyi vielä kaksi - kolme vuotta nurmen jälkeenkin. Mikrobiologista aktiivisuutta kohottanut jälkivaikutus oli myös parempi tavanmukaisten nurmien kuin luonnonmukaisten - ja tăssă tutkimuksessa - huonosti talvehtineiden nurmien jälkeen. Maan dehydrogenaasiaktiivisuus kărsi erittäin selvăsti vuosina 1984 ja 1985 luonnonmukaisilla apilaruuduilla epăonnistuneen talvehtumisen seuraksena. Maan mikrobiologista aktiivisuu'ta ja satoa (KoRVA ja VARIS 1990) ajatellen luonnonmukaisten nurmien talvenkestävyyden olisi oltava hyvă. 